\title{
Extracellular Alkalinization as a Defense Response in Potato Cells
}

\author{
Natalia Moroz', Karen R. Fritch², Matthew J. Marcec ${ }^{1,3}$, Diwaker Tripathi', \\ Andrei Smertenko ${ }^{3,4}$ and Kiwamu Tanaka ${ }^{1,3 *}$
}

'Department of Plant Pathology, Washington State University, Pullman, WA, USA, ${ }^{2}$ Agricultural and Food Systems, Washington State University, Pullman, WA, USA, ${ }^{3}$ Molecular Plant Sciences Program, Washington State University, Pullman, WA, USA, ${ }^{4}$ Institute of Biological Chemistry, Washington State University, Pullman, WA, USA

OPEN ACCESS

Edited by:

Jeremy Astier,

Helmholtz Zentrum München,

Germany

Reviewed by:

Dennis Halterman,

United States Department

of Agriculture - Agricultural Research

Service, USA

Roy Navarre,

United States Department

of Agriculture, USA

*Correspondence:

Kiwamu Tanaka

kiwamu.tanaka@wsu.edu

Specialty section:

This article was submitted to

Plant Biotic Interactions,

a section of the journal

Frontiers in Plant Science

Received: 25 October 2016

Accepted: 06 January 2017

Published: 24 January 2017

Citation:

Moroz N, Fritch KR, Marcec MJ,

Tripathi D, Smertenko A and

Tanaka K (2017) Extracellular

Alkalinization as a Defense Response

in Potato Cells. Front. Plant Sci. 8:32.

doi: 10.3389/fpls.2017.00032
A quantitative and robust bioassay to assess plant defense response is important for studies of disease resistance and also for the early identification of disease during preor non-symptomatic phases. An increase in extracellular $\mathrm{pH}$ is known to be an early defense response in plants. In this study, we demonstrate extracellular alkalinization as a defense response in potatoes. Using potato suspension cell cultures, we observed an alkalinization response against various pathogen- and plant-derived elicitors in a dose- and time-dependent manner. We also assessed the defense response against a variety of potato pathogens, such as protists (Phytophthora infestans and Spongospora subterranea) and fungi (Verticillium dahliae and Colletotrichum coccodes). Our results show that extracellular $\mathrm{pH}$ increases within $30 \mathrm{~min}$ in proportion to the number of pathogen spores added. Consistently with the alkalinization effect, the higher transcription level of several defense-related genes and production of reactive oxygen species was observed. Our results demonstrate that the alkalinization response is an effective marker to study early stages of defense response in potatoes.

Keywords: extracellular alkalinization, apoplastic $\mathrm{pH}$, potato, suspension cell culture, defense response

\section{INTRODUCTION}

The innate immunity of plants allows them to resist a wide variety of biotic stresses. Plants sense potential pathogen attacks by recognizing conserved molecules among microbes, so-called pathogen-associated molecular patterns (PAMPs), while plants are also able to sense damaged-self by recognizing damage-associated molecular pattern (DAMPs) which are released from plant cells upon damage or pathogen infection. PAMPs and DAMPs induce plant defenses, pattern-triggered immunity, which is qualitatively similar to those activated during the gene-for-gene resistance or effector-triggered immunity (Jones and Dangl, 2006).

Pattern-triggered immunity is a set of multiple early defense responses directed to increase plant resistance against stress. Plant stress responses vary significantly across different hosts and pathogens (Atkinson and Urwin, 2012; Rejeb et al., 2014). These differences include the production of plant hormones, reactive oxygen species (ROS), and nitric oxide, as well as dynamic changes in ion balance leading to increases in 
cytosolic calcium levels and rapid extracellular alkalinization (Felle, 2001; Nurnberger and Scheel, 2001; Torres et al., 2006; Bellin et al., 2013; Seybold et al., 2014; Wu et al., 2014; Verma et al., 2016). Furthermore, transcriptional changes in stress-responsive genes lead to the synthesis of pathogenesisrelated proteins and the production of low molecular mass secondary metabolites, e.g., phytoalexins (Ahuja et al., 2012) and antimicrobial peptides (Brotman et al., 2009).

The potato is one of the world's most important vegetable crops. Many diseases caused by various biotic and abiotic factors significantly affect the yield and quality of the potatoes produced (Kapsa, 2008). Although recognition of potato tuber diseases during pre- or non-symptomatic phases is important, little is known about pathogen-induced defense responses in potatoes. Only a few methods have been reported for evaluation of potato defense responses; e.g., ROS assays and expression of pathogen-related genes (Niebel et al., 1995; Kolomiets et al., 2000; Arseneault et al., 2004; Kobayashi et al., 2007; Halim et al., 2009; Sánchez et al., 2010; Gao et al., 2013; Wiesel et al., 2015). In addition, measurement of phytoalexins such as rishitin, lubimin, and solavetivone (Tomiyama et al., 1968; Brindle et al., 1983) is a direct way to evaluate plant defense response. However, these assays are time consuming and require specialized equipment or reagents which may not be available to many labs.

Analysis of stress responses in plant organs can be confounded by tissue-specific responses. To overcome this potential caveat, suspension cell culture systems are commonly used as a simple and highly reproducible system to study plant stress responses. For example, soybean cell cultures were used to detect intracellular calcium changes in response to fungal spores (Navazio et al., 2007), while tobacco suspension cells were used to analyze calcium-based signaling induced by pathogenand plant-derived elicitors (Manzoor et al., 2012). Moreover, pine, tobacco, Arabidopsis and grapevine suspension cells were used to study plant and microbial peptides involved in innate immune responses (Popp et al., 1997; Pearce et al., 2001, 2008; Fammartino et al., 2007; Shirron and Yaron, 2011; Chang and Nick, 2012). Tomato suspension cells were used to study fungal virulence factors (Masachis et al., 2016), the replication of potato spindle tuber viroids (Zelcer et al., 1981), and the effect of general elicitors on the accumulation of phosphatidic acid (van der Luit et al., 2000). Finally, sweet potato suspension cells were used to study defense signaling peptides (Chen et al., 2008) and early stress responses by the yeast elicitor invertase (Debarry et al., 2005). There are a few limitations in the use of the suspension culture system, which requires maintenance of aseptic condition and occasionally does not reflect the in vivo situation, i.e., heterogeneous. However, given its simplicity and high reproducibility of data, the suspension culture is the most convenient system for obtaining accurate results.

Here, we propose a method to measure early response to stress in potato suspension culture cells using extracellular alkalinization as proxy. The rationale for this approach is that extracellular alkalinization is one of the earliest responses to biotic stress (Wu et al., 2014). The objective of our work here is to create a simple, reliable, and fast method to detect a defense response in potato cells. Our results suggest that the alkalinization assay is a powerful method to evaluate early plant defense response against pathogen-derived and plant-derived elicitors as well as external pathogens.

\section{MATERIALS AND METHODS}

\section{Elicitors}

Potato, tomato and pepper systemins (Constabel et al., 1998) were a generous gift from Gregory Pearce. Flg22 (22 amino acids flagellin peptide), Elf26 (conserved amino terminus of bacteria elongation factor EF-Tu) and AtPEP (plant elicitor peptides from Arabidopsis) were synthesized by GenScript, Inc. (Piscataway, NJ, USA). Chitin 6-mer and OGA (oligogalacturonic acid; degree of polymerization $=10-15$ ) were synthesized by Elicityl-OligoTech (France). Chitin mixture (from shrimp shells) and ATP were obtained from Sigma-Aldrich.

\section{Pathogen Spore Preparation and Quantification}

Phytophthora infestans was grown on rye agar (Ribeiro, 1978) for 7 days at $23^{\circ} \mathrm{C}$ with a $16 \mathrm{~h}$ light cycle. Fresh leaves of potato (cv. Russet Burbank) were rinsed with deionized water and placed on a glass tray lined with a moist paper towel and mesh to minimize possible cross-contamination. To initiate $P$. infestans sporulation, rye agar plugs (5-mm in diameter) were placed on the adaxial side of the potato leaves. The tray was covered with a transparent plastic bag, sealed and incubated at $15^{\circ} \mathrm{C}$ for 7 10 days in the dark. Potato leaves with late blight (black/brown) lesions were rinsed with sterile deionized water. To release the zoospores sporangia suspension was incubated for $2 \mathrm{~h}$ in the dark at $4^{\circ} \mathrm{C}$.

Spongospora subterranea inoculum was prepared from potato root galls collected by Dr. Dennis Johnson from a commercial potato field in Washington State in 2001. The inoculum was prepared using a modification of a previously reported method (Merz, 1989). To obtain cystosori of S. subterranea, the powder of the infected root gall tissue was resuspended in Hoagland's solution No 2, pH 7.5 (Caisson Laboratories, Inc., Smithfield, UT, USA) and incubated for 6 days at room temperature with orbital shaking at $150 \mathrm{rpm}$ in the dark.

The fungi, Verticillium dahliae and Colletotrichum coccodes, were grown in media with a half-strength of Potato Dextrose Agar (BD Difco) for 10-15 days (Melouk, 1992; Carnegiea et al., 2003). Grown mycelium was scraped from the plate surface and resuspended in 3-5 mL of sterile deionized water. The suspension was filtered through a layer of Kimwipes.

Pathogens spores/spore balls were quantified using a hemocytometer (Hausser Scientific, Horsham, PA, USA) under a light microscope (ICC50 HD, Leica) at 40-60x magnification.

\section{Maintenance of Suspension Cells Cultures}

Potato suspension cell culture derived from potato tuber (Solanum tuberosum L. cv. Russet Burbank) was kindly provided by Dr. Jeffrey Suttle (Law and Suttle, 2005). The cell suspension 
was grown in Murashige and Skoog (MS) medium ( $\mathrm{pH}$ 5.8) containing $4.3 \mathrm{~g} / \mathrm{L} \mathrm{MS}$ salt with Vitamins (Caisson Laboratories, Inc.), $30 \mathrm{~g} / \mathrm{L}$ (w/v) sucrose, $0.5 \mathrm{mg} / \mathrm{L}(\mathrm{w} / \mathrm{v}) \alpha$-Naphthaleneacetic acid (NAA), and $1 \mathrm{mg} / \mathrm{L}$ (w/v) 2,4-dichlorophenoxyacetic acid (2,4-D). The potato cells were grown at $23^{\circ} \mathrm{C}$ with orbital shaking at $130 \mathrm{rpm}$ in the dark. The potato cell suspension was maintained in $250 \mathrm{ml}$ flasks by transferring $30 \mathrm{~mL}$ of cell culture to $60 \mathrm{~mL}$ of fresh medium every 7 days.

Potato suspension cells images were done using light microscope (DMI $3000 \mathrm{~B}$, Leica). The size of the potato cells at days 3 and 7 after passaging was calculated as mean \pm SE of 100 cells using ImageJ software ${ }^{1}$.

Arabidopsis T87 cells, obtained from Arabidopsis Biological Resource Center (Columbus, OH, USA), were cultured aseptically in NT-1 medium containing $4.3 \mathrm{~g} / \mathrm{L}(\mathrm{w} / \mathrm{v}) \mathrm{MS}$ salt, $30 \mathrm{~g} / \mathrm{L}(\mathrm{w} / \mathrm{v})$ sucrose, $0.18 \mathrm{~g} / \mathrm{L}(\mathrm{w} / \mathrm{v}) \mathrm{KH}_{2} \mathrm{PO}_{4}, 1 \mathrm{mg} / \mathrm{L}(\mathrm{w} / \mathrm{v})$ thiamine, $5 \mathrm{mg} / \mathrm{L}(\mathrm{w} / \mathrm{v})$ 2,4-D, and $100 \mathrm{mg} / \mathrm{L}(\mathrm{w} / \mathrm{v})$ myo-Inositol ( $\mathrm{pH} 5.8$ adjusted with $5 \mathrm{~N} \mathrm{NaOH}$ ). The cell culture was grown at room temperature $\left(22-26^{\circ} \mathrm{C}\right)$ with orbital shaking at $130 \mathrm{rpm}$ in the light. The cell suspension was maintained by transferring $4 \mathrm{~mL}$ of the cell culture to $76 \mathrm{~mL}$ of fresh medium every 7 days.

\section{Measurement of Apoplastic pH}

Seven-day old suspension cell culture was transferred into fresh medium. Three to 4 days after transfer, $1.3 \mathrm{~mL}$ of suspension potato cells were aliquoted into each well of 24well cell culture plates (Greiner Bio-One, max volume $3.3 \mathrm{~mL}$ ). The cells experience a spike in $\mathrm{pH}$ after they are aliquoted, and they equilibrate to $\mathrm{pH} 4.5-5.0$ after 2-4 h of shaking at room temperature, $180 \mathrm{rpm}$. Elicitors and pathogen spores were resuspended in sterile deionized water to make stock solutions. The $\mathrm{pH}$ of the pathogens spores' suspensions was adjusted to that in the equilibrated potato cells culture ( $\mathrm{pH} 4.5-5.0)$. The stock solutions of elicitors and pathogen spores were then diluted stepwise with sterile deionized water to obtain the desired concentrations. The equal volumes of all solutions of elicitors or pathogen spores (or water only as control treatment) were applied to the suspension cells. The added volumes varied from 10 to $600 \mu \mathrm{L}$ depending on the elicitor/pathogen spores stock concentrations. The $\mathrm{pH}$ was recorded using an Accumet AB15 basic $\mathrm{pH}$-meter with an accuTupH electrode (Fisher Scientific). Changes in the extracellular $\mathrm{pH}(\Delta \mathrm{pH})$ were calculated using the following equation:

$$
\begin{gathered}
\Delta \mathrm{pH}=\left(\mathrm{pH}_{\text {sample }}-\mathrm{pH}_{\text {control }}\right) \pm \delta \\
\delta=\sqrt{\left(\delta_{\text {sample }}\right)^{2}+\left(\delta_{\text {control }}\right)^{2}}
\end{gathered}
$$

where $\mathrm{pH}_{\text {control }}$ and $\mathrm{pH}_{\text {sample }}$ are an average $\mathrm{pH}$ and $\delta$ is the standard error (mean $\pm \mathrm{SE}$ of three replicates in three independent experiments). The $\mathrm{pH}$ of potato cell suspensions after application of only sterile deionized water was used as a control. For the time-dependent experiments, the change in $\mathrm{pH}$ was compared to the control at each time point respectively.

\footnotetext{
${ }^{1}$ https://imagej.nih.gov/ij/
}

To exclude a possible false positive $\mathrm{pH}$ shift, pathogen spore suspensions were tested using MS medium only (without potato cells); alkalinization of MS medium in the presence of the same concentrations of pathogens was not observed. Student's $t$-test was performed to determine a significant difference between samples.

\section{Luminol-Based Oxidative Burst Assay}

Potato suspension culture cells $(200 \mu \mathrm{L})$ were transferred to a single well of a white 96-well microplate (PerkinElmer). For the assay $10 \mathrm{x}$ solution consists of $1 \mathrm{mM}$ of L-012, highly sensitive luminol derivative (Wako Chemicals USA, Inc.) and $200 \mu \mathrm{g} / \mathrm{mL}$ of horseradish peroxidase (Sigma-Aldrich) with or without elicitors (10 $\mathrm{mM}$ chitin or $0.25 \mathrm{mM}$ systemin) or pathogens spores $\left(1 \times 10^{5}\right.$ spores $/ \mathrm{mL}$ of $V$. dahliae, $C$. coccodes, and $P$. infestans; or $1 \times 10^{5}$ spore balls $/ \mathrm{mL}$ of S. subterranea) was used. Mock treatment (as a control) was performed by applying the equal volume of sterile deionized water. After $2 \mathrm{~h}$ of cells' pre-incubation at room temperature (no shaking), $22 \mu \mathrm{L} 10 \mathrm{x}$ assay solution, was added and luminescence from each well was measured during $1 \mathrm{~s}$ for each time point using an EnSpire multimode plate reader (PerkinElmer).

\section{Quantitative Real-Time Reverse Transcription (qRT)-PCR}

After treatment of potato culture cells by elicitors or pathogens, the supernatant was discarded and the cells were frozen in liquid nitrogen and stored at $-80^{\circ} \mathrm{C}$. Total RNA was extracted using TRIzol reagent (Invitrogen). The frozen potato cells were partially thawed on ice and then crushed with ceramic beads for $30 \mathrm{~s}$ using Mini-Beadbeater (Biospec). Debris was pelleted by centrifugation for $10 \mathrm{~min}$ at $13,000 \mathrm{rpm}, 4^{\circ} \mathrm{C}$ (Centrifuge 5415R, Eppendorf). Chloroform was mixed with the supernatant (1/5 volume of TRIzol used) and the suspension centrifuged for $10 \mathrm{~min}$ at $13,000 \mathrm{rpm}, 4^{\circ} \mathrm{C}$. Total RNA was precipitated from the supernatant by adding $100 \%$ isopropanol (1/2 volume of TRIzol used). The RNA pellet was washed with $70 \%$ Ethanol (same volume of TRIzol used) followed by centrifugation. Total RNA was resuspended in $100 \mu \mathrm{L}$ of MilliQ RNase free water, and its concentration quantified. First strand cDNA was synthesized from $1 \mu \mathrm{g}$ total RNA using an iScript cDNA Synthesis Kit (Bio-Rad). Real time RT-PCR was performed using SsoAdvanced Universal SYBR Green Supermix Kit (Bio-Rad) with a CFX96 Real-Time System (Bio-Rad). Sequence information of the forward and reverse primers for the reference genes and the potato defense-related genes are listed in Table 1. Cytoplasmic ribosomal protein L2 (L2) and ubiquitin $(U b q)$ were used as reference genes for expression data normalization. Cq (quantification cycle) was estimated from a linear regression fit through the points of the log-linear phase of the amplification curve. Using the $\mathrm{Cq}$ value, gene expression levels relative to a reference gene were calculated for each sample using the following equation (Schmittgen and Livak, 2008):

$$
2^{-\Delta C q}=\frac{2^{-\Delta C q^{\text {Sample }}}}{2^{-\Delta C q^{\text {Ref }}} .}
$$


TABLE 1 | Primers sequences for potato housekeeping genes (L2 and Ubq) and defense genes used in this study.

\begin{tabular}{|c|c|c|c|}
\hline Gene & Accession no. & $5^{\prime}-3^{\prime}$ sequence & Reference \\
\hline \multirow[t]{2}{*}{ L2 } & 39816659 & F: GGCGAAATGGGTCGTGTTAT & Nicot et al., 2005 \\
\hline & & R: CATITCTCTCGCCGAAATCG & \\
\hline \multirow[t]{2}{*}{ Ubq } & BQ045862 & F: CTCCGTGGTGGTATGCAGAT & Gonzalez-Lamothe et al., 2008 \\
\hline & & R: CACGTTGTCAATGGTGTCG & \\
\hline \multirow[t]{2}{*}{ PAL-1 } & X63103 & F: TTGCACAAGTTGCATCCATT & Wang et al., 2008 \\
\hline & & R: CACCAGCTCTTGCACTITCA & \\
\hline \multirow[t]{2}{*}{ PAL-2 } & X63104 & F: GGTCACTGCCTCGGGTGAT & Arseneault et al., 2004 \\
\hline & & R: CCTGCCAGTGAGCAAACCA & \\
\hline \multirow[t]{2}{*}{$P R-1 b$} & AY050221 & F: GGCATCCCGAGCACAAAAT & Arseneault et al., 2004 \\
\hline & & R: CTGCACCGGAATGAATCAAGT & \\
\hline \multirow[t]{2}{*}{ PR-5 } & AY737317.1 & F: GGAGGCAGACGACTCGACTा & Arseneault et al., 2004 \\
\hline & & R: CCATGGTTGTTCCTGGATTCA & \\
\hline \multirow[t]{2}{*}{ HMG-2 } & AB041031 & F: ACAAGAAGCCAGCAGCAGTT & Wang et al., 2008 \\
\hline & & R: CCACAAGAGCAGCAACTTCA & \\
\hline \multirow[t]{2}{*}{ WRKY } & DMG402007388 & F: AAAATATGGTCAAAAAGTGACAAGAG & Wiesel et al., 2015 \\
\hline & & R: CATGTTGGTGCAAATGAACAC & \\
\hline
\end{tabular}

Statistical analysis of the values of three biological replicates was performed by Student's $t$-test to calculate probability of induction or repression. The mean value of the control treatment was used to determine the fold change in transcript level.

\section{RESULTS}

\section{Optimization of Alkalinization Assay Conditions Using Potato Suspension Cells}

We first checked the range of $\mathrm{pH}$ of the MS medium (5.56.0) to get optimal efficiency of the alkalinization assay, and found that $\mathrm{pH} 5.8$ was the optimal for both cell growth and the sensitivity of the alkalinization assay. To evaluate the optimal dilution factor for the cells passaging, the cells culture derived from potato tuber was diluted every 7 days with MS fresh medium at the ratios culture:medium $1: 10$ or $1: 3$. The highest $\mathrm{pH}$ response was detected at 1:3 dilution. The time after cells transfer was also evaluated. In these assays we treated cells culture after 3 or 7 days of the passaging with a known potato DAMP, systemin. Although, time after cell transfer did not change potato cells morphology (Figures 1A-C), the cell size was increased and swollen cells were observed (Figures 1B,C). As shown in Figure 1D, majority of cells at day 7 were $>100 \mu \mathrm{m}$ in length, whereas $<100 \mu \mathrm{m}$ at day 3 . The width of the potato cells was 1.2 times greater in average $(40.29 \pm 10.85 \mu \mathrm{m}$ at day 7 in comparison to $33.52 \pm 7.34 \mu \mathrm{m}$ at day 3 ), while the length was 2.3 times longer in average $(137.74 \pm 75.28 \mu \mathrm{m}$ at day $7 \mathrm{in}$ comparison to $60.06 \pm 27.75 \mu \mathrm{m}$ at day 3 ). The alkalinization response of the potato cells against systemin was markedly higher in cells at day 3 after passaging (Figure 1E). We further evaluated the pre-incubation time at room temperature before recording the $\mathrm{pH}$. We carried out the experiments after 2, 4, and $6 \mathrm{~h}$ of pre-incubation and found that the most efficient extracellular alkalinization can be detected after $4 \mathrm{~h}$ of pre-incubation in the culture plate (Figure 1F) and adhered to this time in the following assays.

\section{Time- and Dose-Dependent Effects of Various Elicitors on the Extracellular pH}

Elicitors are molecules known to trigger plant defense in plants (Hahn, 1996) and are generally classified as pathogenderived elicitors, PAMPs, and plant-derived elicitors, DAMPs. We tested several PAMPs (purified chitin 6-mer, Flg22, and Elf26) and DAMP (systemin and OGA) at two different concentrations. Systemin and chitin produced a significantly higher alkalinization effects when compared to the other elicitors (Figure 2A). Although, Flg22 and Elf26 is widely used in plant defense studies (Felix et al., 1999; Kunze et al., 2004), no alkalinization was observed for potato suspension cells when these elicitors were added at $1 \mu \mathrm{M}$ concentration. The scarce, but significant increase of extracellular $\mathrm{pH}$ was detected in response to $8 \mu \mathrm{M}$ of Flg22, Elf26 (Table 2). OGA was reported to induce extracellular alkalinization at concentrations 7.5-50 $\mu \mathrm{g} / \mathrm{mL}$ (Spiro et al., 2002). However, for the potato suspension cells, the alkalinization effect by OGA addition was small $(\Delta \mathrm{pH}$ was 0.12 and 0.17 at the concentration of 10 and $50 \mu \mathrm{g} / \mathrm{mL}$, respectively). Further, we performed the time-dependent experiment with chitin and systemin as representatives of the elicitor groups since their strong alkalinization effects. Results showed that extracellular alkalinization was initiated in the first few minutes after addition of chitin mixture, and reach their maximum within 5 min followed by a slow reduction during next $15 \mathrm{~min}$ (Figure 2B). In contrast, alkalinization is slowly culminated in approximately $15-20 \mathrm{~min}$ in the presence of systemin. This kinetic difference was observed at the other concentrations we tested. To demonstrate the sensitivity of our alkalinization assay, we measured effect of systemin and chitin in a dose-dependent response. A marked alkalinization was observed in cultures 

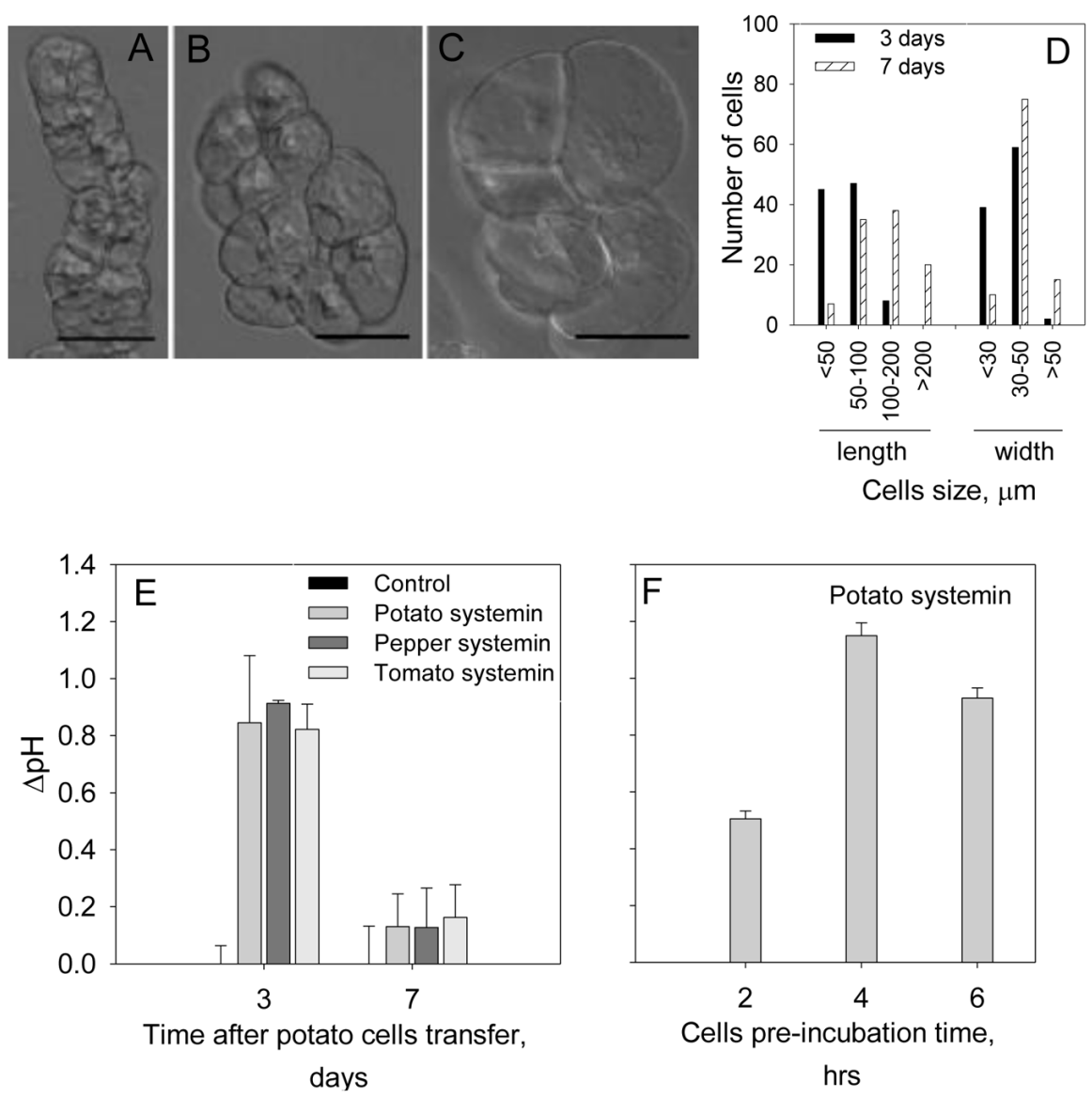

FIGURE 1 | Optimization of conditions for potato suspension cells to use for the alkalinization assay. Photographs show representative light microscope images of the potato suspension cells: $(\mathbf{A})$ at day $3 ; \mathbf{B}, \mathbf{C})$ at day 7 after transfer for subculture. Scale bars $=50 \mu \mathrm{m}$. Note that the morphology was not changed during 7 days after passaging the cells while cells size was increased. (D) The length and width of 100 cells at each time point after passaging was measured under the microscope. (E) Effect of the days after passaging the cells on the efficiency of the alkalinization assay in the presence of $2 \mu \mathrm{M}$ of potato, pepper and tomato systemins. (F) Efficiency of the alkalinization assay as a function of the cells' pre-incubation time prior to the treatment with $2 \mu \mathrm{M}$ potato systemin. Histograms show mean \pm SE of three replicates in three independent experiments.

exposed to even $2 \mathrm{nM}$ of systemin or $4 \mathrm{ng} / \mathrm{mL}$ of chitin mixture (Figures 2C,D).

Next we examined host-specific alkalinization effects caused by identical elicitors. We exposed potato and Arabidopsis suspension cells to PAMPs (Flg22, Elf26, and chitin mixture) and DAMPs (OGA, ATP, AtPEP, and systemin). As shown in Table 2, the alkalinization effect of AtPEP from Arabidopsis is significantly stronger in Arabidopsis suspension cells, while systemin from potato stimulated alkalinization only in potato suspension cells. These results are consistent with previous reports showing species specificity in the peptidic DAMPs (Lori et al., 2015).

\section{Dynamic Changes in Extracellular pH in Response to Potato Pathogens}

Extracellular alkalinization was monitored in the presence of several potato pathogens: S. subterranea, $P$. infestans, $V$. dahliae, and $C$. coccodes. The pathogens were added to the potato suspension cells at the indicated concentrations and the $\mathrm{pH}$ was recorded. As shown in Figure 3, the levels of extracellular alkalinization increased in a dose-dependent manner. The bellshaped time-dependent alkalinization response peaked at $25 \mathrm{~min}$ $(\Delta \mathrm{pH}=0.35-1.0)$ when the potato cells were incubated in the presence of all pathogens (Figures 3A,C,D), except for $P$. infestans. In the presence of $P$. infestans the extracellular $\mathrm{pH}$ was gradually increased in during $60 \mathrm{~min}$ of cells incubation at all tested pathogen concentrations (Figure 3B).

\section{Oxidative Burst Response in Potato Suspension Cells}

An oxidative burst is the rapid release of ROS from stressed plant cells upon contact with pathogens. This robust method is sensitive enough to capture dynamic changes in ROS production at an early time point in infected tissues (Smith and Heese, 2014). To detect this early ROS response, a luminolbased assay was performed in the presence of the same elicitors and pathogens as in alkalinization assay (Figure 4). In consistence with the alkalinization assay, ROS production 

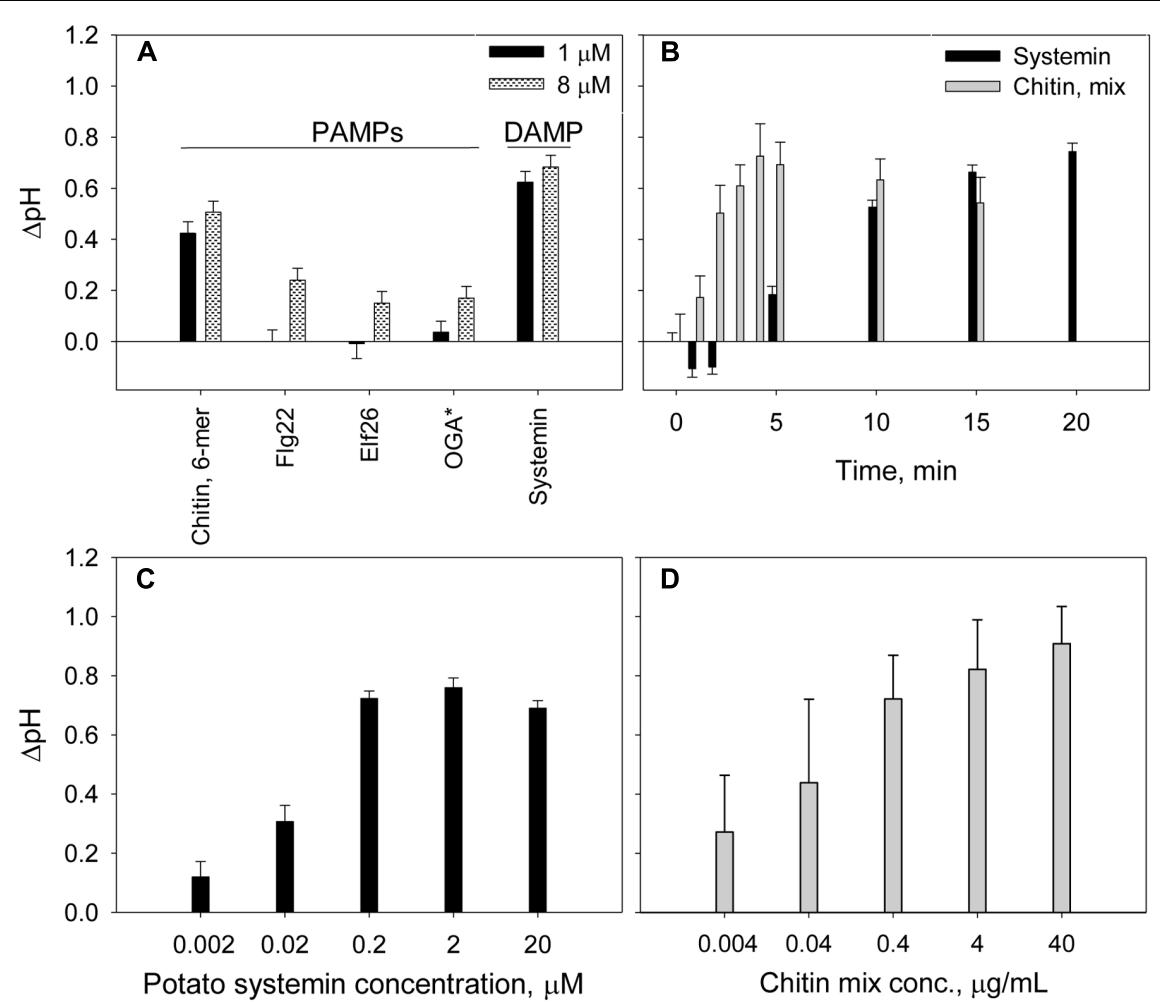

FIGURE 2 | Time- and dose-dependent extracellular alkalinization of potato suspension cells in the presence of elicitors. (A) Effect of PAMP and DAMP elicitors on the extracellular $\mathrm{pH}$ changes. *OGA concentrations were $1 \mu \mathrm{g} / \mathrm{mL}$ (black) and $10 \mu \mathrm{g} / \mathrm{mL}$ (gray pattern). (B) Effect of $2 \mu \mathrm{M}$ of potato systemin and $4 \mu \mathrm{g} / \mathrm{mL}$ of chitin oligomers mixture on extracellular pH over $20 \mathrm{~min}$. (C,D) Alkalinization effect of potato systemin and chitin mixture, respectively, at various concentrations. The $\mathrm{pH}$ was recorded after 15 and $5 \mathrm{~min}$ of suspension cells incubation with systemin and chitin, respectively. Histograms show mean \pm SE of three replicates in three independent experiments.

TABLE 2 | Comparison of the alkalinization effect of various elicitors on the potato and Arabidopsis suspension cells.

\begin{tabular}{|c|c|c|c|c|}
\hline \multirow[t]{2}{*}{ Elicitor } & & \multirow[t]{2}{*}{ Elicitor concentration } & \multicolumn{2}{|c|}{$\Delta \mathrm{pH}^{\S}$} \\
\hline & & & Potato suspension cells & Arabidopsis suspension cells \\
\hline \multirow[t]{5}{*}{ PAMPs } & Flg22 & $1 \mu \mathrm{M}$ & $0.05 \pm 0.028$ & $0.29 \pm 0.029^{* * *}$ \\
\hline & & $8 \mu \mathrm{M}$ & $0.08 \pm 0.039^{*}$ & $0.53 \pm 0.031^{* * *}$ \\
\hline & Elf26 & $1 \mu \mathrm{M}$ & $0.08 \pm 0.050$ & $0.33 \pm 0.240^{* * *}$ \\
\hline & & $8 \mu \mathrm{M}$ & $0.15 \pm 0.046^{*}$ & $0.64 \pm 0.033^{* * *}$ \\
\hline & Chitin 6-mer & $8 \mu \mathrm{M}$ & $0.51 \pm 0.042^{* * *}$ & $0.71 \pm 0.283^{* * *}$ \\
\hline \multirow[t]{4}{*}{ DAMPs } & OGA & $10 \mu \mathrm{g} / \mathrm{mL}$ & $0.12 \pm 0.045^{* *}$ & $0.17 \pm 0.039^{*}$ \\
\hline & ATP & $500 \mu \mathrm{M}$ & $0.21 \pm 0.048^{*}$ & $0.41 \pm 0.032^{* * *}$ \\
\hline & AtPep1 & $1 \mu \mathrm{M}$ & $0.08 \pm 0.048$ & $0.76 \pm 0.256^{* * *}$ \\
\hline & Potato systemin & $0.25 \mu \mathrm{M}$ & $0.84 \pm 0.044^{* * *}$ & $0.12 \pm 0.047^{*}$ \\
\hline
\end{tabular}

${ }^{\circledR}$ The alkalinization was recorded in 5 min after ATP addition, in 60 min after OGA addition and in 15 min for all other elicitors.

${ }^{*} P<0.05 ;{ }^{* *} 0.001<P<0.01 ; * * * P<0.001$ compared to the corresponding values of each control treatment.

was not observed when Flg22 (1 and $10 \mu \mathrm{M})$, Elf26 (1 and $10 \mu \mathrm{M})$, and ATP $(0.5 \mathrm{mM})$ were added to potato cell suspension (Supplemental Figure S1). Chitin 6-mer and fungal pathogens ( $V$. dahliae and $C$. coccodes) induced oxidative bursts within first $10 \mathrm{~min}$ (Figures 4A,B). Systemin and $S$. subterranea induced broader peaks of ROS production in comparison to those induced by the other treatments (Figures $4 \mathbf{A}, \mathbf{B}$ ). Interestingly, in the presence of $P$. infestans the increase in
ROS level was observed only after $20 \mathrm{~min}$ of incubation (Figure 4B).

\section{Expression of Defense-Related Genes in Potato Suspension Cells}

To confirm the correlation between the observed extracellular alkalinization and pathogen response, we quantified transcription of defense-related genes by qRT-PCR in total RNA from 

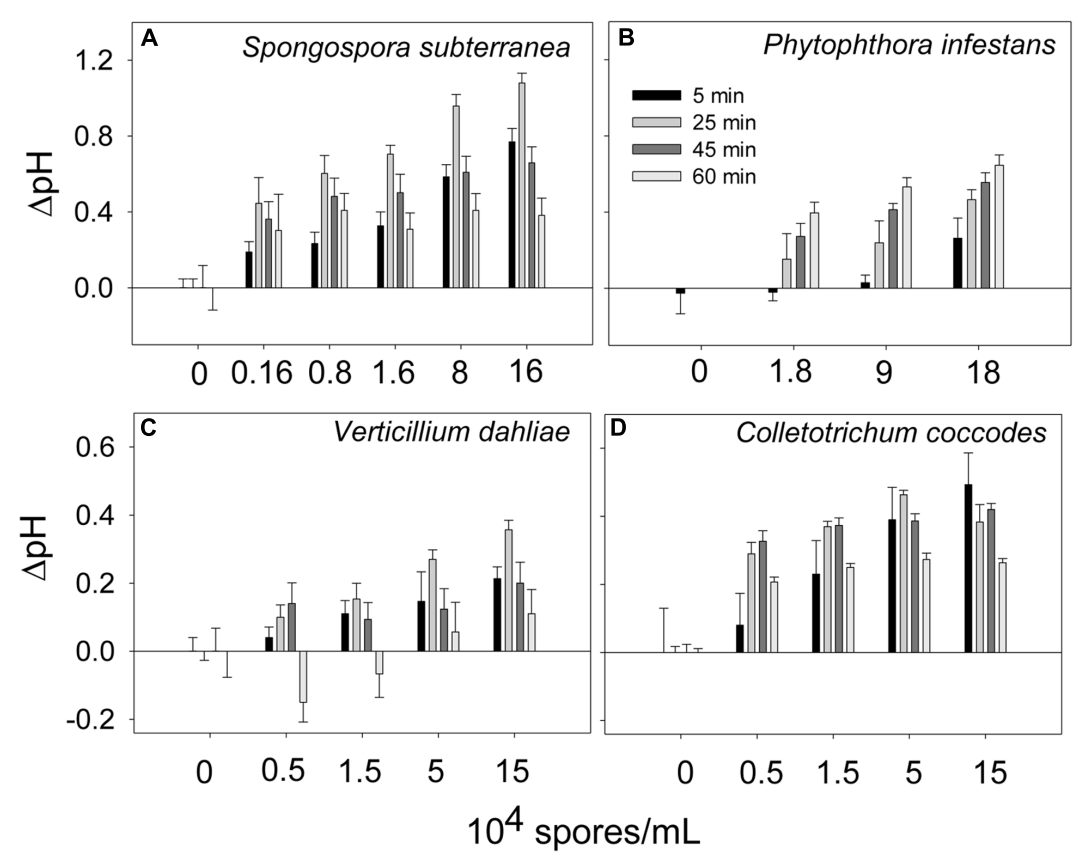

FIGURE 3 | Time- and dose-dependent extracellular alkalinization of potato suspension cells in the presence of potato pathogens. The pH was recorded in 5, 25, 45, and 60 min after addition of spores of Spongospora subterranea (A), Phytophthora infestans (B), Verticillium dahliae (C), and Colletotrichum coccodes (D). Histograms show mean \pm SE of three replicates in three independent experiments.

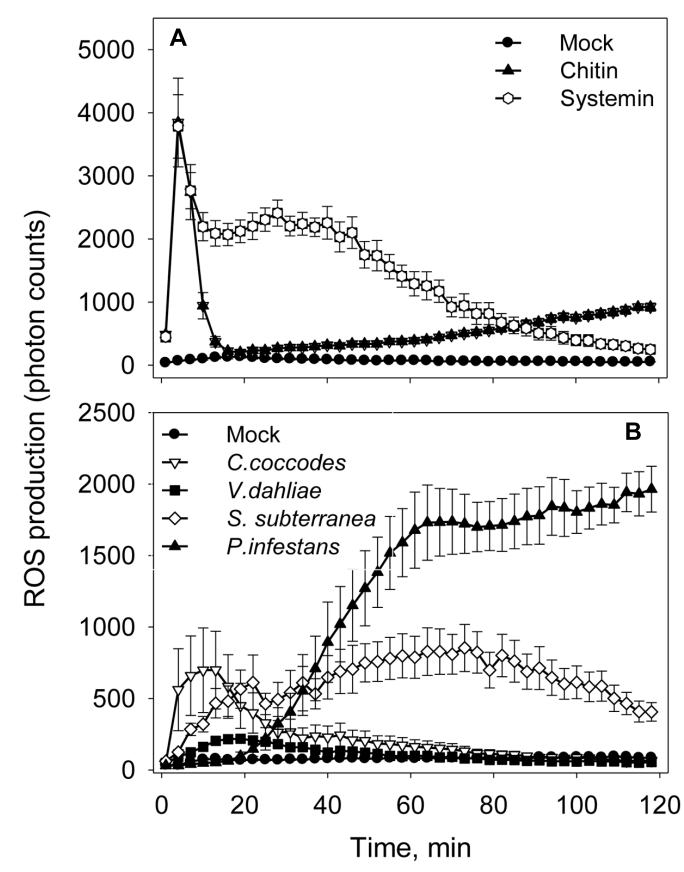

FIGURE 4 | Elicitors- and pathogens-induced reactive oxygen species (ROS) accumulation in potato cells. (A) Time-dependent ROS production in the presence of elicitors (10 $\mu \mathrm{M}$ of Flg22, Elf26, or chitin 6-mer; $0.5 \mathrm{mM}$ of ATP or $1 \mu \mathrm{M}$ Systemin). (B) Time-dependent ROS production in the presence of pathogens $\left(1 \times 10^{5}\right.$ spores $/ \mathrm{mL}$ of $V$. dahliae, C. coccodes, or P. infestans; or $1 \times 10^{5}$ spore balls $/ \mathrm{mL}$ of $S$. subterranea). Data show photon counts in $1.0 \mathrm{~s}$ at each time point with mean $\pm \operatorname{SE}(n=6)$. potato cells treated with elicitors or pathogens for $60 \mathrm{~min}$ (Figure 5). The results show that expressions of salicylic acidresponsive PAL-1, PAL2, and WRKY (similar to AtWRKY40; Wiesel et al., 2015) were upregulated by 2.5 times or more in the presence of systemin and chitin relatively to the non-treated control. Transcription of HMG-2 and PR-5 was only slightly upregulated by both elicitors (Figures $\mathbf{5 A}, \mathbf{B}$ ). Expression of $P R-1 b$ was not affected by chitin, however, was increased by three times in the presence of systemin. Effect of both fungal pathogens, $V$. dahliae and $C$. coccodes, was very similar; expression of PAL-1, PAL-2, and WRKY was increased by twofold and more, however the upregulation of $H M G-2, P R-1 b$, and $P R-5$ was not prominent (Figures 5C,D). S. subterranea led to significant upregulation of $P A L-1, P A L 2$, and $W R K Y$, while the expression of $P R-1 b, P R-5$, and $H M G-$ 2 genes was changed slightly (Figure 5E). In the contrast with other pathogens, transcription of HMG-2 was highly upregulated (eight times) in the presence of $P$. infestans. Expression of WRKY, $P R-1 b, P R-5$, and $P A L-1$ was significantly increased, while no changes were observed in $P A L-2$ expression (Figure 5F).

\section{DISCUSSION}

A combination of different detection methods for the whole spectrum of plant defense responses will facilitate unraveling complexity of the molecular processes underlying immunity in potatoes. Several methods have been applied for evaluating defense responses in potatoes including measurements of ROS 

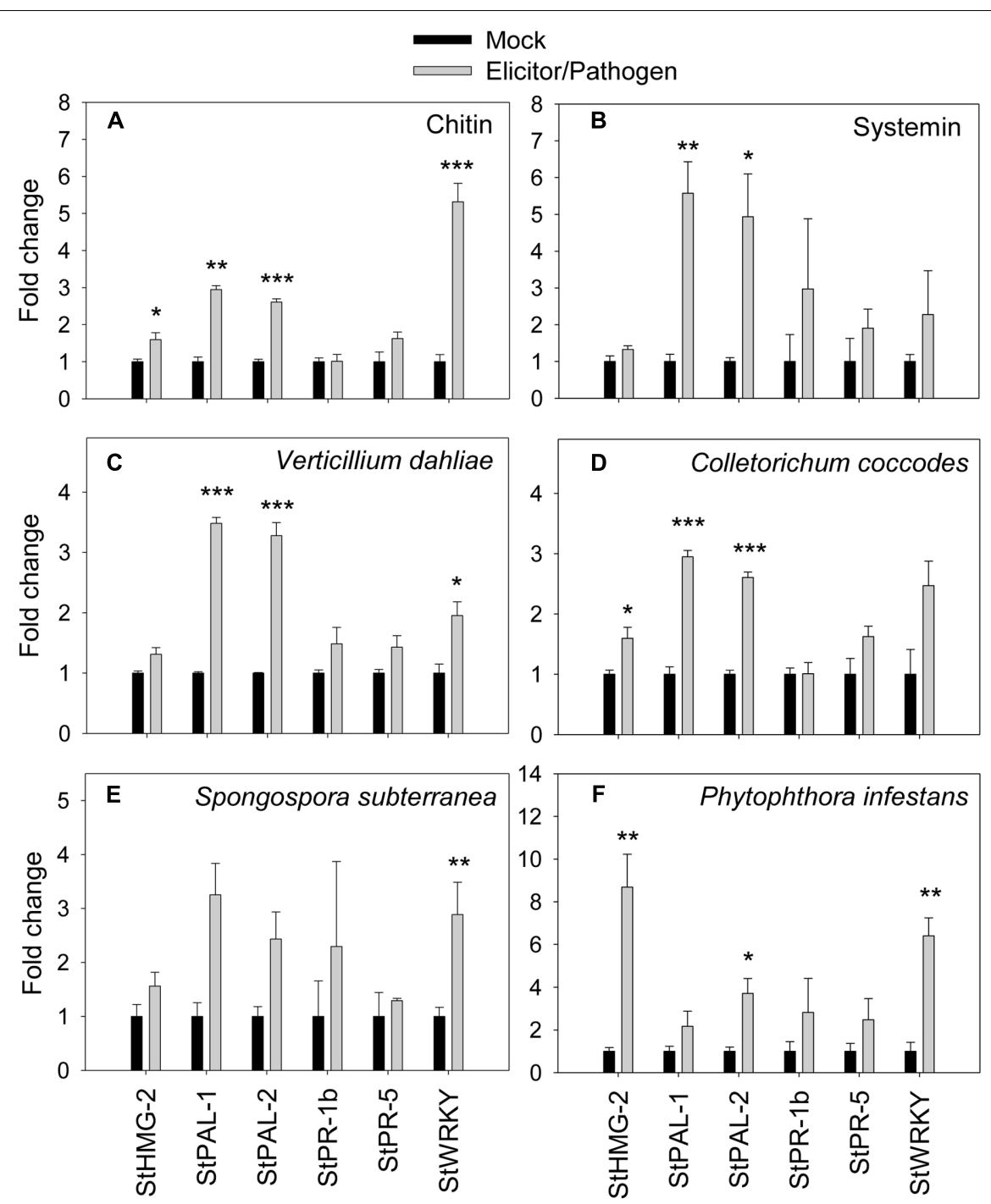

FIGURE 5 | Effects of elicitors and pathogens on expression of defense-related genes. Amplification of potato defense-related genes were monitored by qRT-PCR after elicitation of potato suspension cells with chitin 6-mer (A), potato systemin (B), V. dahliae (C), C. coccodes (D), S. subterranea (E), and P. infestans (F). Histograms show the normalized expression data with mean \pm SE of three biological replications. ${ }^{*} P<0.05 ;{ }^{* *} 0.001<P<0.01 ;{ }^{* * *} P<0.001$ compared to the corresponding values of each control treatment.

production, secondary metabolite accumulations (oxylipins, phytoalexins, etc.), and transcriptional expression of defenserelated genes (Niebel et al., 1995; Kolomiets et al., 2000; Arseneault et al., 2004; Kobayashi et al., 2007; Halim et al., 2009; Sánchez et al., 2010; Sapko et al., 2011; Gao et al., 2013; Wiesel et al., 2015). In the present study, we propose a method for measuring extracellular alkalinization in response to elicitors and pathogens using potato suspension cell culture. Changes in the extracellular alkalinization is one of the earliest responses to biotic stresses (Felix et al., 1999) and could be used for the early identification of disease during pre- or non-symptomatic phases. Although, alkalinization assays have been successfully used to identify and characterize plant-derived elicitors in a number of species (Pearce and Ryan, 2003; Scheer et al., 2003; Huffaker et al., 2006; Pearce et al., 2009, 2010; Chang and Nick, 2012), their usefulness in potato system has not been evaluated thus far. Here, we demonstrate applicability of extracellular alkalinization assay for the potato suspension cell culture.

Assays using suspension cell cultures are a useful system to study plant defense responses. Several applications using potato suspension cells have been reported for studies of plant stress responses. For example, leaf-derived potato suspension cells were used to study resistance to osmotic stress (Sabbah and Tal, 1990) and to measure accumulation of phytoalexins (Brindle et al., 1983), biosynthesis of oxylipins (Stumpe et al., 2001), nitric oxide and ROS production (Sapko et al., 2011), and expression of defense-related genes (Monjil et al., 2014). Most notably, exposure of suspension cells established from potato leaf protoplasts to cutin monomers induces alkalinization, production of ethylene, and transcriptional up-regulation of the 
defense-related genes (Schweizer et al., 1996). In our work, the alkalinization was detected in response to both PAMPs and DAMPs and also to spores of pathogens. This point out versatility of the potato suspension culture cells for evaluating different types of the response. In addition, our study expands the capability of alkalinization assays by showing reliable fast responses against pathogens and damage.

Another important aspect of our study is optimization conditions for an efficient alkalinization assay using potato suspension cells. It has been shown that characteristics of the suspension cell cultures could depend on the type of initiating tissues (Law and Suttle, 2005; Lecourieux et al., 2005; Navazio et al., 2007; Pearce et al., 2008; Manzoor et al., 2012). Furthermore, efficiency of an assay depends significantly on the age of the culture (Popp et al., 1997). As shown in Figure 1, the most efficient conditions for the maximum extracellular alkalinization response were observed $3 \mathrm{~d}$ after the passaging and with a lower dilution.

We demonstrated the high sensitivity of the alkalinization assay using potato cell culture in the presence of elicitors, such as chitin and systemin, which correlates with the published data on the extracellular alkalinization of Arabidopsis suspension cells after treatment with synthetic AtPep1 (Pearce et al., 2010), tomato cells with RALF, Rapid Alkalinization Factor (Masachis et al., 2016), and tobacco cells with synthetic ultrashort cationic lipopeptides (Brotman et al., 2009) at nanomolar elicitors' concentrations. Relatively higher concentrations of the wellknown bacterial elicitors Flg22 and Elf26 (in comparison to the other elicitors we tested) were required to induce alkalinization in potato cell suspensions when compared with that for Arabidopsis (Figure 2; Table 2). One possible explanation is that our cell culture was derived from tubers which express lower levels of the corresponding receptors than above-ground organs. Plausibly, compatible combination of the elicitor and a host species ought to be used to achieve the strongest response. Tissue-specific and species-selective elicitation has been already reported for several elicitors, for example: (1) Flg22 from different sources induces distinct defense response in tobacco, tomato, and potato plants (Hao et al., 2014); (2) in Arabidopsis, shoots and roots respond to chitin and Pep1, whereas roots are insensitive to Elf26 and only had a minor increase in $\mathrm{Ca}^{2+}$ levels in response to Flg22 (Ranf et al., 2011); (3) another group of elicitors, fungal glucans, triggers defense responses in various plants, including tobacco, rice, tomato and potato with different efficiency (Fesel and Zuccaro, 2016); (4) the level of defense genes expression for potato foliage and tuber is different under the treatment of the late blight pathogen $P$. infestans (Gao and Bradeen, 2016). These results suggest that the mechanism of PAMP recognition depends on the plant tissues and species, and further studies of defense responses using potato cells derived from different tissues can help to elucidate these various mechanisms.
Although, extracellular alkalinization is an essential defense response, the nature of the response remains unknown. It has been attributed to a modification of plasma membrane permeability for calcium ions, protons, potassium ions, and anion fluxes that can follow changes in extracellular $\mathrm{pH}$ (Felix et al., 1999). Alternatively, alkalinization can be caused by secretion of cationic protein: a theory supported by a recent report showing that a rust-induced secreted protein in the poplar tree is a small cationic antifungal protein that induces extracellular alkalinization (Petre et al., 2016). Identification of a protein or ion channel responsible for extracellular alkalinization in potato will further accelerate our understanding of molecular mechanisms of plant defense and eventually contribute to engineering disease resistance into potatoes and other crops.

\section{AUTHOR CONTRIBUTIONS}

NM designed the experiments, performed the experiments, analyzed and interpreted the data, wrote and edited the paper. MM, DT, KF, and AS performed the experiments, reviewed the manuscript and wrote comments. KT conceived and designed the experiments, analyzed and interpreted the data, revised the work critically for important intellectual content, approved the final version of the paper to be published.

\section{FUNDING}

This project was supported by the Northwest Potato Research Consortium (to KT), and also by the WSU CAHNRS Undergraduate Internship program (to KF) and the $\mathrm{NIH}$ Biotechnology Training Program (to MM). PPNS No. 0720, Department of Plant Pathology, College of Agriculture, Human and Natural Resource Sciences, Agricultural Research Center, Hatch Project No. WNP00833, Washington State University, Pullman, WA 99164-6430, USA.

\section{ACKNOWLEDGMENTS}

We are grateful to Dr. Jeffrey Suttle (USDA-ARS) for providing potato suspension cells; Drs Lee Hadwiger, Dennis Johnson, and David Wheeler at Washington State University (WSU) for providing pathogens and helpful discussion; and Gregory Pearce at WSU for helping with the experimental set-up.

\section{SUPPLEMENTARY MATERIAL}

The Supplementary Material for this article can be found online at: http://journal.frontiersin.org/article/10.3389/fpls.2017.00032/ full\#supplementary-material 


\section{REFERENCES}

Ahuja, I., Kissen, R., and Bones, A. M. (2012). Phytoalexins in defense against pathogens. Trends Plant Sci. 17, 73-90. doi: 10.1016/j.tplants.2011. 11.002

Arseneault, T., Pieterse, C. M., Gérin-Ouellet, M., Goyer, C., and Filion, M. (2004). Long-term induction of defense gene expression in potato by Pseudomonas $\mathrm{sp}$. LBUM223 and Streptomyces scabies. Phytopathology 104, 926-932. doi: 10.1094/ PHYTO-11-13-0321-R

Atkinson, N. J., and Urwin, P. E. (2012). The interaction of plant biotic and abiotic stresses: from genes to the field. J. Exp. Bot. 63, 3523-3543. doi: 10.1093/jxb/ ers100

Bellin, D., Asai, S., Delledonne, M., and Yoshioka, H. (2013). Nitric oxide as a mediator for defense responses. Mol. Plant Microbe Interact. 26, 271-277. doi: 10.1094/MPMI-09-12-0214-CR

Brindle, P. A., Kuhn, P. J., and Threlfall, D. R. (1983). Accumulation of phytoalexins in potato-cell suspension cultures. Phytochemistry 22, 2719-2721. doi: 10.1016/ S0031-9422(00)97679-9

Brotman, Y., Makovitzki, A., Shai, Y., Chet, I., and Viterbo, A. (2009). Synthetic ultrashort cationic lipopeptides induce systemic plant defense responses against bacterial and fungal pathogens. Appl. Environ. Microbiol. 75, 5373-5379. doi: 10.1128/AEM.00724-09

Carnegiea, S. F., Choiseulb, J. W., and Robertsc, A. M. I. (2003). Detection of Colletotrichum coccodes and Helminthosporium solani in soils by bioassay. Plant Pathol. 52, 13-21. doi: 10.1046/j.1365-3059.2003. 00794.x

Chang, X., and Nick, P. (2012). Defence signalling triggered by Flg22 and Harpin is integrated into a different stilbene output in Vitis cells. PLoS ONE 7:e40446. doi: 10.1371/journal.pone.0040446

Chen, Y. C., Siems, W. F., Pearce, G., and Ryan, C. A. (2008). Six peptide wound signals derived from a single precursor protein in Ipomoea batatas leaves activate the expression of the defense gene sporamin. J. Biol. Chem. 283, 11469-11476. doi: 10.1074/jbc.M709002200

Constabel, C. P., Yip, L., and Ryan, C. A. (1998). Prosystemin from potato, black nightshade, and bell pepper: primary structure and biological activity of predicted systemin polypeptides. Plant Mol. Biol. 36, 55-62. doi: 10.1023/A: 1005986004615

Debarry, M., Marten, I., Ngezahayo, A., and Kolb, H.-A. (2005). Differential defense responses in sweet potato suspension culture. Plant Sci. 168, 1171-1179. doi: 10.1016/j.plantsci.2004.12.016

Fammartino, A., Cardinale, F., Gobel, C., Mene-Saffrane, L., Fournier, J., Feussner, I., et al. (2007). Characterization of a divinyl ether biosynthetic pathway specifically associated with pathogenesis in tobacco. Plant Physiol. 143, 378-388. doi: 10.1104/pp.106.087304

Felix, G., Duran, J. D., Volko, S., and Boller, T. (1999). Plants have a sensitive perception system for the most conserved domain of bacterial flagellin. Plant J. 18, 265-276. doi: 10.1046/j.1365-313X.1999.00265.x

Felle, H. H. (2001). pH: signal and messenger in plant cells. Plant Biol. 3, 577-591. doi: $10.1055 /$ s-2001- 19372

Fesel, P. H., and Zuccaro, A. (2016). beta-glucan: crucial component of the fungal cell wall and elusive MAMP in plants. Fungal Genet. Biol. 90, 53-60. doi: 10.1016/j.fgb.2015.12.004

Gao, L., and Bradeen, J. M. (2016). Contrasting potato foliage and tuber defense mechanisms against the late blight pathogen Phytophthora infestans. PLoS ONE 11:e0159969. doi: 10.1371/journal.pone.0159969

Gao, L., Tu, Z. J., Millett, B. P., and Bradeen, J. M. (2013). Insights into organspecific pathogen defense responses in plants: RNA-seq analysis of potato tuber-Phytophthora infestans interactions. BMC Genomics 14:340. doi: 10.1186/ 1471-2164-14-340

Gonzalez-Lamothe, R., Boyle, P., Dulude, A., Roy, V., Lezin-Doumbou, C., Kaur, G. S., et al. (2008). The transcriptional activator Pti4 is required for the recruitment of a repressosome nucleated by repressor SEBF at the potato PR-10a gene. Plant Cell 20, 3136-3147. doi: 10.1105/tpc.108. 061721

Hahn, M. G. (1996). Microbial elicitors and their receptors in plants. Annu. Rev. Phytopathol. 34, 387-412. doi: 10.1146/annurev.phyto.34.1.387

Halim, V. A., Altmann, S., Ellinger, D., Eschen-Lippold, L., Miersch, O., Scheel, D., et al. (2009). PAMP-induced defense responses in potato require both salicylic acid and jasmonic acid. Plant J. 57, 230-242. doi: 10.1111/j.1365-313X.2008 03688.x

Hao, G., Pitino, M., Ding, F., Lin, H., Stover, E., and Duan, Y. (2014). Induction of innate immune responses by flagellin from the intracellular bacterium, 'Candidatus Liberibacter solanacearum.' BMC Plant Biol. 14:211. doi: 10.1186/ s12870-014-0211-9

Huffaker, A., Pearce, G., and Rya, C. A. (2006). An endogenous peptide signal in Arabidopsis activates components of the innate immune response. Proc. Natl. Acad. Sci. U.S.A. 103, 10098-10103. doi: 10.1073/pnas.0603727103

Jones, J. D., and Dangl, J. L. (2006). The plant immune system. Nature 444, 323-329. doi: 10.1038/nature05286

Kapsa, J. S. (2008). Important threats in potato production and integrated pathogen/pest management. Potato Res. 51, 385-401. doi: 10.1007/s11540-0089114-1

Kobayashi, M., Ohura, I., Kawakita, K., Yokota, N., Fujiwara, M., Shimamoto, K., et al. (2007). Calcium-dependent protein kinases regulate the production of reactive oxygen species by potato NADPH oxidase. Plant Cell 19, 1065-1080. doi: $10.1105 /$ tpc.106.048884

Kolomiets, M. V., Chen, H., Gladon, R. J., Braun, E. J., and Hannapel, D. J. (2000). A leaf lipoxygenase of potato induced specifically by pathogen infection. Plant Physiol. 124, 1121-1130. doi: 10.1104/pp.124.3.1121

Kunze, G., Zipfel, C., Robatzek, S., Niehaus, K., Boller, T., and Felix, G. (2004). The $\mathrm{N}$ terminus of bacterial elongation factor Tu elicits innate immunity in Arabidopsis plants. Plant Cell 16, 3496-3507. doi: 10.1105/tpc.104.026765

Law, R. D., and Suttle, J. C. (2005). Chromatin remodeling in plant cell culture: patterns of DNA methylation and histone $\mathrm{H} 3$ and $\mathrm{H} 4$ acetylation vary during growth of asynchronous potato cell suspensions. Plant Physiol. Biochem. 43, 527-534. doi: 10.1016/j.plaphy.2005.03.014

Lecourieux, D., Lamotte, O., Bourque, S., Wendehenne, D., Mazars, C., Ranjeva, R., et al. (2005). Proteinaceous and oligosaccharidic elicitors induce different calcium signatures in the nucleus of tobacco cells. Cell Calcium 38, 527-538. doi: 10.1016/j.ceca.2005.06.036

Lori, M., van Verk, M. C., Hander, T., Schatowitz, H., Klauser, D., Flury, P., et al. (2015). Evolutionary divergence of the plant elicitor peptides (Peps) and their receptors: interfamily incompatibility of perception but compatibility of downstream signalling. J. Exp. Bot. 66, 5315-5325. doi: 10.1093/jxb/erv236

Manzoor, H., Chiltz, A., Madani, S., Vatsa, P., Schoefs, B., Pugin, A., et al. (2012). Calcium signatures and signaling in cytosol and organelles of tobacco cells induced by plant defense elicitors. Cell Calcium 51, 434-444. doi: 10.1016/j.ceca. 2012.02.006

Masachis, S., Segorbe, D., Turra, D., Leon-Ruiz, M., Furst, U., El Ghalid, M., et al. (2016). A fungal pathogen secretes plant alkalinizing peptides to increase infection. Nat. Microbiol. 1, 1-8. doi: 10.1038/nmicrobiol.2016.43

Melouk, H. A. (1992). "Verticillium," in Methods for Research on Soilborne Phytopathogenic Fungi, eds L. L. Singleton, J. D. Mihail, and C. M. Rush (St. Paul, MN: American Phytopathological Society Press), 175-178.

Merz, U. (1989). Infectivity, inoculum density and germination of Spongospora subterranea resting spores: a solution-culture test system. Bull. OEPP 19, 585592. doi: 10.1111/j.1365-2338.1989.tb00436.x

Monjil, M. S., Takemoto, D., and Kawakita, K. (2014). Defense induced by a bisaryl methanone compound leads to resistance in potato against Phytophthora infestans. J. Gen. Plant Pathol. 80, 38-49. doi: 10.1007/s10327-0130493-z

Navazio, L., Moscatiello, R., Genre, A., Novero, M., Baldan, B., Bonfante, P., et al. (2007). A diffusible signal from arbuscular mycorrhizal fungi elicits a transient cytosolic calcium elevation in host plant cells. Plant Physiol. 144, 673-681. doi: 10.1104/pp.106.086959

Nicot, N., Hausman, J. F., Hoffmann, L., and Evers, D. (2005). Housekeeping gene selection for real-time RT-PCR normalization in potato during biotic and abiotic stress. J. Exp. Bot. 56, 2907-2914. doi: 10.1093/jxb/eri285

Niebel, A., Heungens, K., Barthels, N., Inze, D., Van Montagu, M., and Gheysen, G. (1995). Characterization of a pathogen-induced potato catalase and its systemic expression upon nematode and bacterial infection. Mol. Plant Microbe Interact. 8, 371-378. doi: 10.1094/MPMI-8-0371

Nurnberger, T., and Scheel, D. (2001). Signal transmission in the plant immune response. Trends Plant Sci. 6, 372-379. doi: 10.1016/S1360-1385(01)02019-2

Pearce, G., Bhattacharya, R., Chen, Y. C., Barona, G., Yamaguchi, Y., and Ryan, C. A. (2009). Isolation and characterization of hydroxyproline-rich 
glycopeptide signals in black nightshade leaves. Plant Physiol. 150, 1422-1433. doi: 10.1104/pp.109.138669

Pearce, G., Moura, D. S., Stratmann, J., and Ryan, C. A. (2001). Production of multiple plant hormones from a single polyprotein precursor. Nature 411, 817-820. doi: 10.1038/35081107

Pearce, G., and Ryan, C. A. (2003). Systemic signaling in tomato plants for defense against herbivores. Isolation and characterization of three novel defensesignaling glycopeptide hormones coded in a single precursor gene. J. Biol. Chem. 278, 30044-30050. doi: 10.1074/jbc.M304159200

Pearce, G., Yamaguchi, Y., Munske, G., and Ryan, C. A. (2008). Structure-activity studies of AtPep1, a plant peptide signal involved in the innate immune response. Peptides 29, 2083-2089. doi: 10.1016/j.peptides.2008.08.019

Pearce, G., Yamaguchi, Y., Munske, G., and Ryan, C. A. (2010). Structure-activity studies of RALF, Rapid Alkalinization Factor, reveal an essential-YISY-motif. Peptides 31, 1973-1977. doi: 10.1016/j.peptides.2010.08.012

Petre, B., Hecker, A., Germain, H., Tsan, P., Sklenar, J., Pelletier, G., et al. (2016). The poplar Rust-Induced Secreted Protein (RISP) inhibits the growth of the leaf rust pathogen Melampsora larici-populina and triggers cell culture alkalinisation. Front. Plant Sci. 7:97. doi: 10.3389/fpls.2016.00097

Popp, M. P., Lesney, M. S., and Davis, J. M. (1997). Defense responses elicited in pine cell suspension cultures. Plant Cell Tissue Organ Cult. 47, 199-206. doi: 10.1007/BF02318973

Ranf, S., Eschen-Lippold, L., Pecher, P., Lee, J., and Scheel, D. (2011). Interplay between calcium signalling and early signalling elements during defence responses to microbe- or damage-associated molecular patterns. Plant J. 68, 100-113. doi: 10.1111/j.1365-313X.2011.04671.x

Rejeb, I. B., Pastor, V., and Mauch-Mani, B. (2014). Plant responses to simultaneous biotic and abiotic stress: molecular mechanisms. Plants (Basel) 3, 458-475. doi: $10.3390 /$ plants3040458

Ribeiro, O. K. (1978). A Source Book of the Genus Phytophthora. Hirschberg: J. Cramer.

Sabbah, S., and Tal, M. (1990). Development of callus and suspension cultures of potato resistant to $\mathrm{NaCl}$ and mannitol and their response to stress. Plant Cell Tissue Organ Cult. 21, 119-128. doi: 10.1007/BF00033430

Sánchez, G., Gerhardt, N., Siciliano, F., Vojnov, A., Malcuit, I., and Marano, M. R. (2010). Salicylic acid is involved in the Nb-mediated defense responses to Potato virus X in Solanum tuberosum. Mol. Plant Microbe Interact. 23, 394-405. doi: 10.1094/MPMI-23-4-0394

Sapko, O. A., S. H., Utarbaeva, A., and Makulbek, S. (2011). Effect of fusaric acid on prooxidant and antioxidant properties of the potato cell suspension culture. Russ. J. Plant Physiol. 58:828. doi: 10.1134/S1021443711050190

Scheer, J. M., Pearce, G., and Ryan, C. A. (2003). Generation of systemin signaling in tobacco by transformation with the tomato systemin receptor kinase gene. Proc. Natl. Acad. Sci. U.S.A. 100, 10114-10117. doi: 10.1073/pnas.1432910100

Schmittgen, T. D., and Livak, K. J. (2008). Analyzing real-time PCR data by the comparative C(T) method. Nat. Protoc. 3, 1101-1108. doi: 10.1038/nprot. 2008.73

Schweizer, P., Felix, G., Buchala, A., Muller, C., and Metraux, J. P. (1996). Perception of free cutin monomers by plant cells. Plant J. 10, 331-341. doi: 10.1046/j.1365-313X.1996.10020331.x

Seybold, H., Trempel, F., Ranf, S., Scheel, D., Romeis, T., and Lee, J. (2014). Ca ${ }^{2+}$ signalling in plant immune response: from pattern recognition receptors to $\mathrm{Ca}^{2+}$ decoding mechanisms. New Phytol. 204, 782-790. doi: 10.1111/nph.13031
Shirron, N., and Yaron, S. (2011). Active suppression of early immune response in tobacco by the human pathogen Salmonella Typhimurium. PLoS ONE 6:e18855. doi: 10.1371/journal.pone.0018855

Smith, J. M., and Heese, A. (2014). Rapid bioassay to measure early reactive oxygen species production in Arabidopsis leave tissue in response to living Pseudomonas syringae. Plant Methods 10:6. doi: 10.1186/1746-4811-10-6

Spiro, M. D., Bowers, J. F., and Cosgrove, D. J. (2002). A comparison of oligogalacturonide- and auxin-induced extracellular alkalinization and growth responses in roots of intact cucumber seedlings. Plant Physiol. 130, 895-903. doi: 10.1104/pp.006064

Stumpe, M., Kandzia, R., Gobel, C., Rosahl, S., and Feussner, I. (2001). A pathogen-inducible divinyl ether synthase (CYP74D) from elicitor-treated potato suspension cells. FEBS Lett. 507, 371-376. doi: 10.1016/S0014-5793(01) 03019-8

Tomiyama, K., Sakuma, T., Ishizaka, N., Sato, N., Katsui, N., Takasugi, M., et al. (1968). A new antifungal substance isolated from resistant potato tuber tissue infected by pathogens. Phytopathology 58, 115-116.

Torres, M. A., Jones, J. D., and Dangl, J. L. (2006). Reactive oxygen species signaling in response to pathogens. Plant Physiol. 141, 373-378. doi: 10.1104/pp.106. 079467

van der Luit, A. H., Piatti, T., van Doorn, A., Musgrave, A., Felix, G., Boller, T., et al. (2000). Elicitation of suspension-cultured tomato cells triggers the formation of phosphatidic acid and diacylglycerol pyrophosphate. Plant Physiol. 123, 1507-1516. doi: 10.1104/pp.123.4.1507

Verma, V., Ravindran, P., and Kumar, P. P. (2016). Plant hormone-mediated regulation of stress responses. BMC Plant Biol. 16:86. doi: 10.1186/s12870-0160771-y

Wang, X., Hadrami, A. E., Adam, L. R., and Daayf, F. (2008). Differential activation and suppression of potato defence responses by Phytophthora infestans isolates representing US-1 and US-8 genotypes. Plant Pathol. 57, 1026-1037. doi: 10. 1111/j.1365-3059.2008.01866.x

Wiesel, L., Davis, J. L., Milne, L., Redondo Fernandez, V., Herold, M. B., Middlefell Williams, J., et al. (2015). A transcriptional reference map of defence hormone responses in potato. Sci. Rep. 5:15229. doi: 10.1038/ srep 15229

Wu, S., Shan, L., and He, P. (2014). Microbial signature-triggered plant defense responses and early signaling mechanisms. Plant Sci. 228, 118-126. doi: 10. 1016/j.plantsci.2014.03.001

Zelcer, A., van Adelsberg, J., Leonard, D. A., and Zaitlin, M. (1981). Plant cell suspension cultures sustain long-term replication of potato spindle tuber viroid. Virology 109, 314-322. doi: 10.1016/0042-6822(81)90502-X

Conflict of Interest Statement: The authors declare that the research was conducted in the absence of any commercial or financial relationships that could be construed as a potential conflict of interest.

Copyright (C) 2017 Moroz, Fritch, Marcec, Tripathi, Smertenko and Tanaka. This is an open-access article distributed under the terms of the Creative Commons Attribution License (CC BY). The use, distribution or reproduction in other forums is permitted, provided the original author(s) or licensor are credited and that the original publication in this journal is cited, in accordance with accepted academic practice. No use, distribution or reproduction is permitted which does not comply with these terms. 